\section{BRS Ártico - Common bean cultivar with export- standard white grain}

\author{
Helton Santos Pereira ${ }^{1 *}$, Adriane Wendland ${ }^{1}$, Thiago Lívio Pes- \\ soa Oliveira de Souza ${ }^{1}$, Luís Cláudio de Faria ${ }^{1}$, Maria José Del \\ Peloso ${ }^{1}$, Michael Thung ${ }^{1}$, João Kluthicouski ${ }^{1}$, Joaquim Geraldo \\ Cáprio da Costa ${ }^{1}$, José Luis Cabrera Díaz ${ }^{1}$, Mariana Cruzick de \\ Souza Magaldi ${ }^{1}$, Ângela de Fátima Barbosa Abreu ${ }^{1}$, Maurício \\ Martins ${ }^{2}$, Israel Alexandre Pereira Filho ${ }^{3}$, José Aloísio Alves \\ Moreira $^{3}$ and Leonardo Cunha Melo ${ }^{1}$
}

\begin{abstract}
BRS Ártico is a common bean cultivar with white grains with international standard size (62 g per 100 seeds), appropriate for cultivation in the Central region of Brazil and the state of Paraná. The cycle is semi-early, the yield potential $2677 \mathrm{~kg} \mathrm{ha}^{-1}$ and BRS Ártico has moderate resistance to rust and curtobacterium wilt.
\end{abstract}

Key words: Phaseolus vulgaris, international market, special grains.

\section{INTRODUCTION}

Brazil is one of the world's largest producers of common bean (Phaseolus vulgaris L.) and a traditional staple food of Brazilians, being consumed across all social classes. However, for lower-income groups, it is the main source of protein, minerals, vitamins, and fiber. The total output of common bean in Brazil was 2.5 million tons in 2013 (Feijão 2014). The market groups carioca and black have Mesoamerican origin and represent $85 \%$ of the Brazilian production. However, there is a demand for other grain types with higher added value and possibility of export (Del Peloso and Melo 2005). Among the market groups of major international interest is the white grain group of Andean origin, with 100 -grain weight between 55 and $65 \mathrm{~g}$, which is sold and consumed in Europe, Asia and the United States (Gonzales et al. 2009). Historically, in Brazil little effort has been invested into breeding programs of Andean common bean, especially for grain types of the international market, including the white grain type. As a result, few cultivars are available, resulting in low domestic production and high imports of this grain type into the country. Currently, some breeding programs have been working on this kind of grain, with a view to develop and identify lines with better adaptation to the soil and climatic conditions of the country (Gonçalves et al. 2010, Pereira et al. 2014).

The release of new cultivars has contributed to increase the common bean yield in Brazil (Feijão 2014). Therefore, the search for new lines with superior phenotypes must be maintained constantly. The common bean breeding program of Embrapa Rice and Beans is focused on the search for varieties with high yield potential, better disease resistance and upright plant architecture, to enable
Crop Breeding and Applied Biotechnology 16: 163-166, 2016 Brazilian Society of Plant Breeding. Printed in Brazil http://dx.doi.org/10.1590/1984$70332016 v 16 n 2 c 25$
${ }^{*}$ Corresponding author:
E-mail:helton.pereira@embrpapa.br

Received: 03 July 2015 Accepted: 16 November 2015

${ }^{1}$ Embrapa Arroz e Feijão, Rod. GO 462, km 12, CP 179, 75.375-000, Santo Antônio de Goiás, GO, Brazil

2 Universidade Federal de Uberlândia, Av. João Naves de Ávila, 2121, CP 593, 38.408100, Uberlândia, MG, Brazil ${ }^{3}$ Embrapa Milho e Sorgo, Rod. MG 424, km 45, 35.701-970, Sete Lagoas, MG, Brazil 
direct mechanical harvesting, so that farmers can offer a high quality product to consumers and obtain higher yields with this crop. In this sense, new cultivars with other grain types than carioca and black have been released in the past years, e.g.: BRSMG Realce (Melo et al. 2014), with red speckled grains; BRS Embaixador (Aidar et al. 2008a), with DRK (dark red kidney) grains; BRS Executivo (Aidar et al. 2008b), with sugar bean grain; and BRSMG União (Ramalho et al. 2012), with jalo (yellow) grains. However, for the white group, only two cultivars are registered, with smaller grain size than required for the international market: Ouro Branco (Chagas et al. 1994), indicated by Epamig/UFV; and IPR Garça, indicated by IAPAR.

\section{BREEDING METHODS}

BRS Ártico was derived from a cross $\{(\mathrm{G} 13922 \times \mathrm{G} 13145) \times\{(\mathrm{G} 13922 \times[\mathrm{G} 07930 \times(\mathrm{A} 156 \times \mathrm{A} 494)]\}\}$, performed in 1985 at CIAT (International Center for Tropical Agriculture, Cali, Colombia). The following generations and lines were also grown in Colombia. The line WAF 75 was introduced and evaluated in the field in Brazil, between 2000 and 2010, for plant architecture, lodging, yield, reaction to angular leaf spot, anthracnose, fusarium wilt, rust, common bacterial blight, curtobacterium wilt, and for commercial quality of grains. In 2000 and 2001, the line was evaluated in the winter season at three locations in a total of 13 tests in the State of Goiás. In 2007, 2008, 2009 and 2010, it was also evaluated in the winter, in Goiás and Minas Gerais and in the rainy and dry seasons in Paraná, totaling 31 evaluation environments. In all 44 tests, four controls were used: Ouro Branco, with white beans, BRS Radiante, with red speckled grains; BRS Executivo, with sugar bean grain; and Jalo Precoce, with jalo grain. The experiments were arranged in a randomized block design with three replications and plots of four 4-m rows, using recommended technologies for the different common bean cropping systems.

\section{GRAIN YIELD AND YIELD POTENTIAL}

In 44 VCU tests conducted in 2000, 2001, 2007, 2008, 2009, and 2010, in the "winter" growing season in Goiás and Minas Gerais and in the "rainy" and "dry" seasons in Paraná, a yield of 92.1\% was observed for BRS Ártico (WAF 75), compared to the mean of the controls (Ouro Branco and BRS Executivo/BRS Radiante/Jalo Precoce) (Table 1). These controls were chosen for being cultivars with Andean origin with "large" grain and suited for export, although not belonging to the same market group as BRS Ártico. This procedure was adopted because there were no other cultivars with the same grain pattern as BRS Ártico at the beginning of the VCU tests. BRS Executivo has sugar bean grains. BRS Radiante has red speckled grains and Jalo Precoce, yellow (jalo) grains, typical of the domestic market, which are occasionally exported when the production in countries which traditionally export other grain types is low. Cultivar Ouro Branco was represented in all experiments, as the standard control. As a second control in the experiments we used BRS Radiante, BRS Executivo or Jalo Precoce. It is worth remembering that Jalo Precoce and BRS Radiante are cultivars with grain types that were already improved in long-term breeding programs and consequently have a better agronomic performance.

The overall mean yield of BRS Ártico was $1632 \mathrm{~kg} \mathrm{ha}^{-1}$, compared with $1819 \mathrm{~kg} \mathrm{ha}^{-1}$ of the controls (Ouro Branco 1870 $\mathrm{kg} \mathrm{ha}^{-1}$ and the others $1768 \mathrm{~kg} \mathrm{ha}^{-1}$ ). In the different States and test regions (Pereira et al. 2009), BRS Ártico produced a mean yield of $1847 \mathrm{~kg} \mathrm{ha}^{-1}$ in Goiás and $1511 \mathrm{~kg} \mathrm{ha}^{-1}$ in Minas Gerais. In region II (Espírito Santo, Rio de Janeiro, Mato Grosso, Goias, Distrito Federal, Bahia, Tocantins, and Maranhão) (Table 1), the mean yield was $1757 \mathrm{~kg} \mathrm{ha}^{-1}$. In the State

Table 1. Grain yield $\left(\mathrm{kg} \mathrm{ha}^{-1}\right)$ of BRS Ártico, compared to the control mean in the tests of Value for Cultivation and Use (VCU), per State and growing season

\begin{tabular}{lccccccc} 
State & $\begin{array}{c}\text { Growing } \\
\text { Season }\end{array}$ & BRS Ártico & Ouro Branco & $\begin{array}{c}\text { BRS Executivo, BRS Radi- } \\
\text { ante or Jalo Precoce }\end{array}$ & $\begin{array}{c}\text { Control } \\
\text { means }\end{array}$ & $\begin{array}{c}\text { Relative yield } \\
\text { (\%) }\end{array}$ & $\begin{array}{c}\text { Number of environ- } \\
\text { ments }\end{array}$ \\
\hline PR & Rainy & 1,162 & 1,526 & 1,627 & 1,577 & 73.7 & 8 \\
PR & Dry & 1,634 & 1,785 & 1,796 & 1,790 & 91.3 & 6 \\
\hline PR & General & 1,364 & 1,636 & 1,699 & 1,668 & 86.5 & 14 \\
\hline MG & Winter & 1,511 & 1,668 & 1,718 & 1,693 & 91.7 & 8 \\
GO & Winter & 1,847 & 2,092 & 1,831 & 1,962 & 95.2 & 22 \\
\hline RII* & Winter & 1,758 & 1,980 & 1,801 & 1,891 & 93.0 & 30 \\
\hline Geral & - & 1,632 & 1,870 & 1,768 & 1,819 & 92.1 & 44 \\
\hline
\end{tabular}

*Region II - ES, RJ, GO, DF, MT, TO, BA and MA. 
of Paraná however, the mean yield was $1364 \mathrm{~kg} \mathrm{ha}^{-1}$.

The yield potential of BRS Ártico, calculated from the mean of the five tests where this cultivar produced highest yields, was $2,677 \mathrm{~kg} \mathrm{ha}^{-1}$. This estimate shows that farming has a high genetic potential and that if the environment is favorable and growing conditions are good, yields can be high. This cultivar has a similar yield as others with large-sized grains (standard for export), such as BRS Executivo and BRS Embaixador.

Based on its performance, BRS Ártico was registered for sowing in the winter in the States of Goiás, Federal District, Mato Grosso, Tocantins, Maranhão, Bahia, Espírito Santo and Rio de Janeiro; and in the rainy and dry seasons in the state of Parana.

\section{OTHER TRAITS}

In terms of grain quality, BRS Ártico has uniform grain color and size, a mean 100-grain weight of $62 \mathrm{~g}$, higher than cultivar Ouro Branco (50 g) (Table 2). The mean cooking time of BRS Ártico is $26 \mathrm{~min}$, within the range observed for other grain types. With regard to the protein percentage of BRS Ártico, the mean content (23.5\%) is within the standard for common bean.

Under artificial inoculation, BRS Ártico is resistant to the pathotypes $65,73,81,89$, and 453 of Colletotrichum lindemuthianum, the causal agent of anthracnose. In field tests, it proved moderately resistant to rust and curtobacterium wilt and moderately susceptible to anthracnose and fusarium wilt. However, it was susceptible to angular leaf spot, curtobacterium wilt, common bacterial blight and golden mosaic virus (Table 3).

BRS Ártico is a semi-early maturing cultivar (75-84 days from emergence to physiological maturity), similar to cv. Ouro Branco. The plants are bushy, with determinate growth habit (type I). In terms of plant architecture, BRS Ártico is upright and has good lodging tolerance. However, due to the short plant height, direct mechanical harvesting (harvesting and threshing in a single operation) may not be effective in all cases. The flowers are white and at physiological maturity the pods are green-yellowish. At harvest maturity, the pods are straw yellow and may be slightly reddish. The beans are white, have a full oblong shape, and intermediate gloss.

The advantages of BRS Ártico are the white beans, with export standard and larger grain size (62g 100 seeds $^{-1}$ ) than the existing white bean cultivars in Brazil (Ouro Branco and IPR Garça) (50 g 100 seeds $^{-1}$ ). This new cultivar will allow Brazilian producers to supply the domestic market with white bean. In addition, the product meets international

Table 2. Grain qualities of common bean cultivar BRS Ártico, compared to the controls Ouro Branco, BRS Radiante, Jalo Precoce, BRS Executivo, and BRS Embaixador

\begin{tabular}{lccc} 
Cultivar & Grain type & $\begin{array}{c}\text { Cooking } \\
\text { time (min.) }\end{array}$ & $\begin{array}{c}\text { Protein } \\
\text { content (\%) }\end{array}$ \\
BRS Ártico & White & 26 & $\begin{array}{c}\text { 100-grain } \\
\text { weight (g) }\end{array}$ \\
Ouro Branco & White & - & 23.5 \\
BRS Radiante & Red speckled & 32 & - \\
Jalo Precoce & Jalo & 26 & 22.3 \\
BRS Executivo & Sugar bean & 29 & 21.8 \\
BRS Embaixador & Dark red kidney & 38 & 24.8 \\
\hline
\end{tabular}

Table 3. Agronomic traits and reaction to diseases of BRS Ártico, compared to the controls Ouro Branco, BRS Embaixador and BRS Executivo

\begin{tabular}{|c|c|c|c|c|c|c|c|c|c|c|}
\hline Cultivar & Cycle & PA & AN & CBC & $\mathbf{R U}$ & ALS & BCMV & BGMV- & FOP & CUR \\
\hline BRS Ártico & SE & Upright & MS & $\mathrm{S}$ & $\mathrm{MR}$ & $\mathrm{S}$ & $\mathrm{SI}$ & $\mathrm{S}$ & MS & $\mathrm{MR}$ \\
\hline Ouro Branco & SE & Upright & MS & $S$ & MR & $\mathrm{S}$ & $\mathrm{SI}$ & $\mathrm{S}$ & SI & $\mathrm{SI}$ \\
\hline BRS Executivo & $\mathrm{N}$ & $\begin{array}{l}\text { Semi- } \\
\text { upright }\end{array}$ & MS & $\mathrm{S}$ & $\mathrm{S}$ & $\mathrm{S}$ & $\mathrm{S}$ & $\mathrm{S}$ & MR & $\mathrm{MR}$ \\
\hline BRS Embaixador & SE & Upright & MR & $S$ & $S$ & $S$ & $S$ & $\mathrm{~S}$ & MR & $S$ \\
\hline
\end{tabular}

M100- 100-grain weight (g); PA- Plant architecture; A- Anthracnose; CBC- common bacterial blight; RU Rust; ALS - angular leaf spot; BCMV-Bean common mosaic virus; BGMV- bean golden mosaic virus; FOP-Fusarium wilt; CUR - Curtobacterium wilt; N-Normal cycle; SE-semi-early cycle; R-resistant; MR-moderately resistant; MS-moderately susceptible; S-Susceptible. 
standards for the export market, which has increased greatly in recent years, with high price stability and good prospects of economic return.

\section{SEED PRODUCTION}

BRS Ártico was registered by the Ministry of Agriculture, Livestock and Supply (MAPA) under number 33731. Embrapa Products and Market is responsible for the seed production of the cultivar.

\section{CONCLUSIONS}

The common bean cultivar BRS Ártico with white beans has semi-early cycle, good yield potential and excellent grain quality, meeting the demand of the Brazilian domestic market and also making trade on the international market possible. BRS Ártico is recommended for sowing in the following States and growing seasons: Goiás, Federal District, Mato Grosso, Tocantins, Maranhão, Bahia, Espirito Santo and Rio de Janeiro in the winter; and in Paranám in the rainy and dry seasons.

\section{ACKNOWLEDGEMENTS}

Partner institutions that contributed in the testphase of the cultivar Embrapa Rice and Beans; Embrapa Technology Transfer; Emater Goiás; Universidade do Centro-Oeste; Fundação de Ensino Superior de Rio Verde; Embrapa Cerrados; Embrapa Maize and Sorghum; Federal University of Lavras; Federal University of Uberlândia; Agricultural Research Corporation of Minas Gerais; Instituto Federal Goiano; Instituto Luterano de Ensino Superior/Universidade Luterana do Brasil; Embrapa Soybean.

\section{REFERENCES}

Aidar H, Thung MD, Kluthicouski J, Soares DM, Del Peloso MJ, Faria LC, Melo LC, Costa JGC, Rava CA, Pereita HS, Díaz JLC, Silva HT, Sartorato A, Faria JC and Bassinello PZ (2008a) BRS Embaixador - Dark red kidney common bean for international market. Annual Report of the Bean Improvement Cooperative 51: 274-275.

Aidar $\mathrm{H}$, Thung MD, Kluthicouski J, Soares DM, Del Peloso MJ, Faria LC, Melo LC, Costa JGC, Rava CA, Pereita HS, Díaz JLC, Silva HT, Sartorato A, Faria JC, Wendland A (2008b) BRS Executivo - Cranberry common bean for international market. Annual Report of the Bean Improvement Cooperative 51: 276-277.

Chagas LM, Araúdo GAA and Vieira C (1994) 'Ouro Branco', Cultivar de feijão branco para Minas Gerais, Revista Ceres 41: 219-220.

Del Peloso MJ and Melo LC (2005) Potencial de rendimento da cultura do feijoeiro comum. Embrapa Arroz e Feijão, Santo Antônio de Goiás, 131p.

Feijão (2014) Dados conjunturais do feijão (área, produção e rendimento) (Phaseolus vulgaris L.) no Brasil - 1985 to 2013. Available at <www. cnpaf.embrapa.br/socioeconomia/index.htm>. Accessed on July 28, 2014.

Gonçalves JGR, Chiorato AF, Morais LK, Perina EF, Farias FL and Carbonell SAM (2010) Estudo da estabilidade fenotípica de feijoeiro com grãos especiais. Ciência e Agrotecnologia 34: 922-931.
Gonzales AM, Rodinõ AP, Santalla M and De Ron AM (2009) Genetics of intra-gene pool and inter-gene pool hybridization for seed traits in common bean (Phaseolus vulgaris L.) germplasm from Europe. Field Crops Research 112: 66-76.

Melo LC, Abreu AFB, Ramalho MAP, Carneiro JES, Paula Júnior TJ, Del Peloso MJ, Pereira HS, Faria LC, Pereira Filho IA, Moreira JAA, Martins M, Vieira RF, Maritns FAD, Coelho MAO, Costa JGC, Wendland A, Santos JB, Diaz JLC, Carneiro PCS, Del Giúdice MP and Faria JC (2014) BRSMG Realce: Common bean cultivar with sprinkled grains for the state of Minas Gerais. Crop Breeding and Applied Biotechnology 14: 61-64.

Pereira HS, Bueno LG, Del Peloso MJ, Abreu AFB, Moreira JAA, Martins M, Wendland A, Faria LC, Souza TLPO and Melo LC (2014) Agronomic performance and stability of andean common bean lines with white grains in Brazil. Bragantia 73: 130-137.

Pereira HS, Melo LC, Silva SC, Del Peloso MJ, Faria LC, Costa JGC, Magaldi MCS and Wendland A (2009) Regionalização de áreas produtoras de feijão comum para recomendação de cultivares no Brasil. Embrapa Arroz e Feijão, Santo Antônio de Goiás, 6p. (Comunicado técnico, 187).

Ramalho MAP, Abreu ÂFB, Santos JB, Santos JB, Carneiro JES, Paula Júnior TJP, Del Peloso MJ, Pereira HS, Melo, LC, Martins M, Vieira RF, Del Giúdice MP, Faria LC, Teixeira H and Carneiro PCS (2012) BRSMG União: common bean cultivar with jalo grain for the state of Minas Gerais. Crop Breeding and Applied Biotechnology 12: 285-288. 